\title{
PROWENIENCJA NIEKTÓRYCH SCHEMATÓW IKONOGRAFICZNYCH PASJI CHRYSTUSA W MALARSTWIE ŚCIENNYM ŚREDNIOWIECZA NA SLOWACJI I W CZECHACH
}

W scenie Opłakiwania z okresu po 1351 r. na ścianie północnej prezbiterium w kościele Narodzenia NMP w Starým Plzencu (il. 1) Maria trzymająca na kolanach ciało Chrystusa, siedząc frontalnie do widza, ma uniesione w górę obie ręce. Głowę Chrystusa podpiera inna kobieta, a nogi mężczyzna. W tle widać głowę mężczyzny o czworokatnym nakryciu głowy (mitry) ${ }^{1}$. W przedstawieniach Złozenia do grobu Czech i Stowacji Chrystus leży w sarkofagu. Dlatego następna scena w Starým Plzencu wyobraża Złożenie do grobu (il. 2), w którym Maria obejmuje Chrystusa leżacego w sarkofagu, a za nią znajdują się następne trzy osoby. W scenach Zlożenia do grobu z około 1385 r. na ścianie połuđniowej prezbiterium w kościele św. Jakuba w Slavĕtinie (i1. 3) Maria usytuowana pośrodku za sarkofagiem załamuje nad głową ręce. Mężczyzna podtrzymuje głowę Chrystusa. Inny stoi za nim, zaś po prawej stronie za sarkofagiem, obok Marii znajduje się kobieta ${ }^{2}$. W tejże scenie na malowidle $\mathrm{z}$ lat dziewięćdziesiątych XIV w. na ścianie północnej w zakrystii kościoła św. Jana Chrzciciela w Zablatiu (il. 4.) Maria, pochylona nad Jezusem w sarkofagu, przytula swoją twarz do policzka Chrystusa. U wezgłowia stoi mężczyzna w mitrze na głowie i podtrzymuje glowę Chrystusa. Inny w kapeluszu żydowskim (pileus) ujmuje nogi Chrystusa. Za sarkofagiem, pośrodku, między kobietą i druga postacią zakrywającą twarz, stoi kobieta i załamuje nad głową ręce ${ }^{3}$.

W malarstwie ściennym na Słowacji w scenie Zlozenia do grobu, za osobami zgrupowanymi nad ciałem Jezusa, ukazana jest kobieta, która ma uniesione do góry \footnotetext{
s. $435-436$.

${ }^{2}$ Soupis památek historyckých a umēleckých v Králostvi českém, od pravēku do počatku XIX stoleti, napisal Dr. Bohumil Matéjka, t. 2, Politický okres Lounsky, V Praze 1897, s. 75, tabl. III.

${ }^{3}$ Miejscowość od 1393 r. należała do Zygmunta Hullera von Orlik, podskarbiego na dworze króla Wacława II ( $Z$. V š e t e č k o v a, Bemerkungen zu den Wandmalereien in Südböhmen, „Uměni" 41, 1993, 3-4, s. 184-187). Niektóre sceny i typy postaw wskazują na to, że malarz musiał znać klasztor Emaus w Pradze lub uczestniczyć jako pomocnik przy dekoracji jego ścian (A. M a r t a n, Restaurováni gotiských maleb kolem r. 1380 v kostele sv. Jana Kr̆titele v Záblati, $v$ kostele Zvěstování P. Marie v Dobrši ze 14-15. stoleti, v kostele sv. Jakuba v Maletnicich, v kostele sv. Mikuláše v Maletnicich, v kostele sv. Mikulase v Boleticich z druchẻ pol. 14. století, „Umẽni” 42, 1993, 3-4, s. 267).
}

'J. R o y t, Starý Plzenec, [w:] Gotíka v západnich Čechách (1230-1530), II, Praha 1996, 
ręce. Takie przedstawienie występuje w Podolincu, Ochtinej, Zolnej, Kocel'ovcach, Švábovcach i Sliačach. Malowidła z połowy XIV w. w kościele Wniebowzięcia Panny Marii w Podolincu, w tym Zlożenie do grobu (il. 5) na ścianie wschodniej prezbiterium, porównano do malowideł w kościele św. Jana w Brixen i w kościele w Popradzie. ${ }^{4}$ Tutaj Maria przytula twarz do policzka leżącego Jezusa. Św. Jan podtrzymuje nogi Jezusa, za nim stoi mężczyzna w kapleuszu żydowskim (pileus), natomiast za Marią w centrum stoi kobieta $z$ uniesionymi do góry rękami. Obok niej stoi inna kobieta, która przykłada krawędź swojego płaszcza do twarzy. Malowidło na ścianie poludniowej prezbiterium w kościele ewangelickim w Ochtinej (il. 6) pochodzi z lat sześćdziesiątych i osiemdziesiątych XIV w. Milan Togner nazwał malarza Mistrzem ochtinskiego prezbiterium. Malowidła maja swoje zakorzenienie w ikonografii włosko-bizantyńskiej. ${ }^{5}$ W Ochtinej do Chrystusowej głowy Maria przytula policzek, a za nią pochylają się do przodu dwie pozostale postacie, kobieta i mężczyzna bez nimbu, który podtrzymuje nogi Chrystusa (Nikodem?). Drugi mężczyzna w nimbie podtrzymuje głowę Chrystusa, młody, a więc zapewne św. Jan (albo Józef $z$ Arymatei). Jedna z kobiet klęczy przed sarkofagiem. Dwie pozostałe kobiety stoja z tyłu za Marią i pochyloną ku Chrystusowi kobieta i mają uniesione do góry ręce, jakby tworzyły nad Chrystusem baldachim. Kobieta po lewej stronie ma je splecione i załamane nad głową, a kobieta po prawej stronie ma je uniesione do góry. Wszystkie kobiety mają nimb wokół głowy. W kościele św. Macieja Apostoła w Zolnej Ztożenie do grobu (il. 7) namalowane jest na północnej ścianie nawy. Malowidło jest datowane przez Tognera na siedemdziesiąte lata XIV w. ${ }^{6}$, natomiast Dvořáková, Krása i Stejskal uznali je jako włosko-neapolitańskie, w nurcie čerinsko-neapolitańskim i rimavskobaňskim ${ }^{7}$. Na malowidle trzech mężczyzn w nimbach, w rzędzie pochylonych jest nad Chrystusem leżącym w sarkofagu, z dekoracią kolumienkową i z trójlistnymi arkadkami na bokach. Pierwszy z mężczyzn jest nieco mlodszy od pozostałych. Zapewne jest to św. Jan, a pozostali - św. Józef z Arymatei i Nikodem. Za nimi stoi Maria z rozłożonymi rękami w geście lamentacji oraz po jej bokach stoją nieco pochylone do przodu, w jej stronę, dwie kobiety w nimbach ze złożonymi dłońmi, splecionymi i załamanymi palcami, przyłożonymi do policzka na znak cierpienia. Nad rękami Marii ukazane są Słońce i Księżyc, a po bokach dłoni, nad kobietami, dwaj aniołowie z kadzielnicami w ręku. Całość jest jakby wzięta $\mathrm{z}$ uroczystości liturgicznej. Metodą fresku pod wpływem Mistrza ochtińskiego i w tym samym czasie co malowidła w Ochtinej i Rybniku powstały malowidła w kościele ewangelickim w Kocel'ovcach, gdzie w południowej ścianie prezbiterium widnieje scena Ztożenia do grobu (il. 8) ${ }^{8}$. Ciało Jezusa do sarkofagu składają Józef z Arymatei i Nikodem. Podobnie jak w Ochtinej Maria tuli swoją twarz do policzka

${ }^{4}$ V. D vo r̃á ková, J. K rása, K. S t e j s a l, Střredověká nástẽnná mal 'ba na Slovensku, Bratislava 1978, s. 129; M. To g n e r, Monumentálna nástenná mal'ba na Spiši 1300-1550, ,Ars" 1992 nr 2, s. 117.

${ }^{5}$ V. D voŕák ová, J. K rás a, K. S tejsk a l, op. cit., s. 128-129; M. Tog n e r, Siředověká nástènná mal'ba v Gemeri, Bratislava 1989, s. 71-72, 74-75, 177-178.

${ }^{6}$ M. T o g n e r, Středovéká násténná mal'ba na Slovensku, Bratislava 1988, s. 114

${ }^{7}$ V. D voĺáková, J. Krása, K. S te j sk al, op. cit., s. 169-170.

${ }^{8}$ Tamże, s. 99-102; M. To g n e r, Středověká nástěnná mal'ba v Gemeri, s. 75, 79, 174; Z. K I iś, Sredniowieczne przedsiawienia pasyjne w malarstwie ściennym na Słowacji, [w:] Charisteria Tito Górski oblata, red. S. Stabryła, R. M. Zawadzki, Kraków 2003, s. 93. 
Chrystusa, a za nią inna kobieta pochyla się i ujmuje prawą rękę zmarkego. W tle, za Józefem u wezgłowia, stoi św. Jan, a dwie kobiety podobnie jak w Ochtinej mają uniesione ręce, jedna $z$ nich, stojaca po lewej stronie (za Nikodemem), załamuje ręce nad głową, a druga, w centrum tła sceny, unosi je i rozwiera w geście rozpaczy. Malowidło z końca XIV w. (według Tognera lata 1370-1380) w kościele św. Filipa i Jakuba w Švábovcach (il. 99 $)^{9}$ W nawie na ścianie północnej odwzorowuje niemal idealnie scenę w Podolincu. Maria tuli się do policzka Chrystusa. Nikodem składa nogi Pana Jezusa. Za nim stoi św. Jan i drugi mężczyzna. Natomiast $\mathrm{w}$ centrum sceny, za Maria, stoi kobieta $\mathrm{z}$ uniesionymi rękami, obok niej stoi inna kobieta, przytykająca krawędź swojego płaszcza do twarzy. Malowidła w kościele św. Szymona i Judy w Sliačach zostały odkryte na strychu, nad sklepieniem nawy głównej i pochodzą z pierwszej połowy XV w. ${ }^{10} \mathrm{~W}$ scenie Złożenia do grobu (il. 10) Maria unosi głowę Chrystusa leżacego w sarkofagu. Od tyłu obejmuje ją inna kobieta, za którą stoi jeszcze jedna, mająca uniesione ręce. W tle stoją zapewne Apostołowie. U wezgłowia Chrystusa stoi mężczyzna podający Marii naczynie, zapewne służące do namaszczenia ciała Chrystusa.

Ponieważ przypuszcza się, że malarze, którzy działali w części dawnych Węgier, a na obecnym terenie Słowacji, pochodzili z Włoch, ze względu na metodę fresku, jaką się posługiwali w malarstwie ściennym, dlatego uzasadnione wydaje się sięgnięcie do rozwiązań bizantyńskich i włoskich, aby ukazać źródło powstania pewnych motywów i typów ikonograficznych. O tym już częściowo wspominali autorzy opracowujący malowidła średniowieczne na terenie obecnej Słowacji. Na wstępie należy wspomnieć, że w sztuce bizantyńskiej i włoskiej nastapiło połączenie niektórych elementów bizantyńskiego Oplakiwania, przed wejściem do groty skalnej, ze Zlożeniem do grobu, we wczesnej sztuce bizantyńskiej ukazanego jako scena niesienia ciała do grobu skalnego przez Józefa z Arymatei i Nikodema. Charakterystyczne w Opłakiwaniu bizantyńskim gesty, na przykład: załamanie rąk nad głowa; uniesienie rąk; przykładanie rąk do twarzy, pokrytych płaszczem; pochylenie się Marii nad leżącym Jezusem i przyłożenie swojego policzka do jego twarzy itd., we Włoszech zostały połączone $\mathrm{z}$ architektonicznym sarkofagiem, do którego uczniowie składają ciało Jezusa.

Pliniusz Starszy w swojej Naturalis historia przedstawiając szereg odkryć w starożytnym malarstwie, które były przypisane konkretnym osobom, zauważył, że malarz zwany Aristides z Teb, współczesny Apellesowi, odkrył, jak wyrazić plastycznie ludzkie emocje, co grecy nazywają ๆ́uๆ... Bizantyńscy pisarze, którzy byli spadkobiercami klasycznych tradycji antycznych, chwalili artystów za umiejętność oddania ludzkich emocji. Henry Maguire postawił sobie za cel przebadać sposób wyrażania ludzkiego żalu w narracji sztuk plastycznych, w Bizanzjum w latach 843-1204, w okresie macedońskim w X w. i sztuce późnych Kommenów w drugiej połowie XII w., kiedy bizantyńscy artyści zainteresowani byli patosem i ludzkimi odczuciami. Podzielił gesty żalu w sztuce bizantyńskiej na trzy kategorie: te, które konstytuowały gwałtowność cierpienia; te, ukazujące cierpienie jako wyraz przeżyć wewnętrznych; te gesty, które były ambiwalentne w swoim znaczeniu, a więc mogly wyrażać także inne emocje - nie tylko żal, ale takie jak ra-

${ }^{9}$ V. Dvớáková, J. Krása, K. Stejskal, op. cit., s. 158-159; M. Togner, Monumentálna nástenná mal'ba na Spiši, dz. cyt., s. 120.

${ }^{10} \mathrm{~V}$. D vořá ková, J. K rá s a, K. S te j sk a I, op. cit., dz. cyt., s. 141. 
dość lub strach. I w tej części Maguire widzi koniecznośc rozważenia takich gestów, dzięki którym cierpiący dają pełny dostęp do swoich przeżyć" . Przy gwałtownych ruchach postacie posypuja glowy popiołem, wyrywają sobie włosy z głowy itp.

Do gwałtownych gestów można zaliczyć już na pokrywie rzymskiego sarkofagu Meleagera w Palazzo Sciarra ruchy rąk Altei. W płaskorzeźbie ukazane jest nagie ciało syna Altei niesione przez kilku mężczyzn, oraz ona sama przytykająca dłonie do głowy. W jednym momencie, kiedy ciało Meleagera składane jest na stosie drewnianych belek, ulożonych w czworobok, Altea stojąc za marami unosi obie ręce na wysokość swojej głowy, odrzucając palcami włosy. W scenie rozpaczy Jakuba na widok splamionych krwią szat jego syna Józefa, na krześle Maximiana z VI w., biskupa Rawenny, tenże siedząc na krześle ma uniesione ręce z dłońmi splecionymi na czubku głowy. Według Maguire’a może to symbolizować odrzucenie włosów lub posypanie popiołem ${ }^{12}$. W miniaturze śmierci Debory w Genesis Wiedeńskiej z VI w. (Wiedeń, Nationalbibliothek, teol. Gr. 31, fol. 13v) kobiety stoją nad zmarłą, a jedna $z$ nich ma uniesione do góry ręce ${ }^{13}$.

Siedzące lub przyklękające postacie, bardziej pasywne, $\mathrm{z}$ rękami uniesionymi na poziomie głowy, wyrażają wewnętrzny żal. W miniaturze ukazującej Opłakiwanie Chrystusa tuż przed grobem skalnym w Lekcjonarzu z XI w. (Biblioteka Watykańska, gr. 1156, fol. 194v) Maria pochyla się nad leżącym na występie skalnym ciałem Jezusa i przykłada głowę do jego policzka. Z tyłu mężczyzna przyklękający całuje lewą dłoń Chrystusa. Dwaj mężczyźni układają nogi Chrystusa. W tle, nad wejściem do grobu, przyklęka kilka kobiet, z których jedna ma uniesione ręce, a pozostałe przykładają skraj swojego płaszcza do twarzy ${ }^{14}$. Ten schemat musiał być powszechnie stosowany, jeżeli został powtórzony w miniaturze Ewangelistarza z XI w. przechowywanego w Parmie. Przy czym w tej ostatniej scenie pośrodku malowidła Opłakiwania umieszczony został krzyż, a usunięta postać całująca rękę Chrystusa ${ }^{15}$.

We wspomnianej Genesis Wiedeńskiej z VI w. ręce uniesione do góry przez kobietę, ale również przytknięte do ust przez kilku uczestników, przysłonięte kawałkiem wierzchniej szaty, zastosowane zostały w miniaturze Śmierci i pogrzebu Jakuba. Przy czym do leżącej postaci patriarchy na łożu pochyla się postać, jak w scenach Optakiwania czyni Maria ${ }^{16}$. Schemat pochylającej się Marii nad leżącym Jezusem, całującej rękę Chrystusa, postaci stojącej za Maria, oraz u wejścia do grobu siedzącej ze złożonymi rękami postaci kobiety, a także za nią innej unoszącej ręce widnieje na fresku z XII w. w monastyrze Mirož w Pskowie. W tle sceny widnieje krzyż ${ }^{17}$.

$"$ H. M a gu ire, The Depiction of Sorrow in Middle Byzantine Art, „Dumbarton Oaks Papers" 31, 1977, s. 125-126.

12 Tamże, s. 127, 129, il. 1, 3. Patrz także: G. B o v i n i, La Cattedra eburnea del Vescovo Massimiano di Ravenna, Ravenna 1990, s. 33, il. na s. 34.

${ }^{13}$ H. M a g u i r e, op. cit., s. 129 , il. 5 .

14 Tamze, s. 144, il. 38.

${ }^{15}$ G. S c h ill e r, Iconography of Christian Art, 2, The Passion of Jesus Christ, London 1972 , il. 594.

${ }^{16} \mathrm{H}$. M a gu ire, op. cit., s. 151, il. 54.

${ }^{17}$ Tamże, s. 156, il. 63. 
Uniesione ręce w sztuce bizantyńskiej należą do wieloznacznych gestów, które mogą wyrażać przeciwstawne uczucia, jak radość i lament, w zależności od kontekstu. Powyższy gest ma takie znaczenia w pisanych tekstach antycznych, jak również wypowiedziach bizantyńskich odnoszących się do Biblii. Niewątpliwie na fresku w kościele Świętej Trójcy w Sopoćani uniesione ręce kobiety u wezgłowia umierającego Jakuba oznaczają dramat i lament ${ }^{18}$. Kobieta stojąca u wezgłowia Jakuba jest odpowiednikiem tej, która stoi u wezgłowia Jezusa w scenie Optakiwania Chrystusa w ołtarzu $z$ lat 1280-1290, nieznanego umbryjskiego malarza (Perugia). W obu przypadkach został zastosowany ten sam schemat kobiety pochylonej nieco do przodu, $\mathrm{z}$ wyciagniętymi do góry rękami, pomiędzy którymi $\mathrm{z}$ wierzchniej szaty opadającej $\mathrm{z}$ rąk na piersiach lamentującej powstał fałd. Głowa kobiety, pochylona do przodu, osadzona jest między rękami, a powyżej tego fałdu. Obaj malarze musieli korzystać ze wspólnego wzoru w malarstwie bizantyńskim ${ }^{19}$.

Spośród wielu przykładów wydaje się, że w Podolincu i w Švábovcach scena Złożenia do grobu odzwierciedla układ skomponowany przez Duccia w Maestà, który także funkcjonował w nieco późniejszym czasie w czternastowiecznym malarstwie sieneńskim i bizantyńskim ${ }^{20}$. W Švábovcach widoczne są jeszcze plyciny chrystusowego sarkofagu na ścianach bocznych, nieco podobnie jak w scenie Duccia. Maria obejmuje ciało Jezusa przytulając policzek do jego twarzy. W Švábovcach koniec tkaniny, w która jest Chrystus owinięty spada w dół, wzdłuż przedniego boku sarkofagu, co także jest widoczne w malowidle Duccia. Nikodem składa nogi Pana Jezusa. Podobnie jest w obrazie Duccia. Jednakże w scenie Duccia przed sarkofagiem stoi jeszcze jeden mężczyzna, pochylony w stronę Jezusa, a głowę zmarłego podtrzymuje św. Jan. U Duccia za sarkofagiem stoją cztery kobiety, z których jedna unosi do góry ręce, pochylając się nad leżącym Jezusem. W Svábovcach za Nikodemem znajduje się zapewne Józef i św. Jan. Za Maria, pośrodku sarkofagu stoi kobieta, która ma uniesione ręce. U wezgłowia umieszczona jest kobieta, która swój płaszcz przytyka do twarzy. W Podolincu to św. Jan (w aureoli) kładzie nogi Chrystusa do sarkofagu, a za nim stoi mężczyzna w żydowskim kapeluszu. W Podolincu kobieta z uniesionymi rękami nad Jezusem jest bardziej wyprostowana i zwrócona do widza niż w Švábovcach. W scenach tych, tak samo jak w sztuce Duccia, Opłakiwanie zostało połączone ze Zlozeniem do grobu.

Scena w Zolnej ze względu na niemal liturgiczny nastój (aniołowie $z \mathrm{ka}-$ dzielnicami) ma swoje odpowiedniki w sztuce wschodniej, gdzie w przedstawieniach w XII w. postać zmarłego Chrystusa leżąca samotnie na skale lub na tkaninie symbolizowała Eucharystię. Na czternastowiecznej tkaninie liturgicznej z Bu-

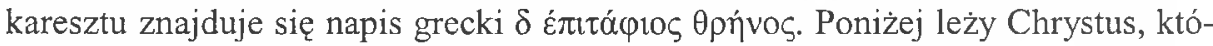
rego obejmuje Maria i przytula do siebie. Za nią stoi pochylony św. Jan. W tle za nimi stoją aniołowie ubrani $\mathrm{w}$ stroje diakońskie i trzymają $\mathrm{w}$ rękach ripidiony. Wszystko razem symbolizuje liturgię niebiańską połączoną z ziemską historią̨

\footnotetext{
${ }^{18}$ Tamże, s. 159 , il. 70

${ }^{19}$ G. S c hille r, op. cit., il. 598.
}

${ }^{20}$ G. Millet, Recherches sur L'iconographie de l'évangile aux XIVe, XVe et XVIe siècles d'après les monuments de Mistra, de la Macédoine et du Mont-Athos, Paris 1960, s. 503-506 , il. 542-547.

${ }^{21}$ Tamże, s. 499-500, il. 536-537. 
W sztuce zachodniej odniesieniem dla takiego przedstawienia jest miniatura w Psałterzu w Besançon z około $1275 \mathrm{r}^{22}$, na której Chrystus leży w sarkofagu. Nikodem poprawia nogi Chrystusa, a Józef stoi u wezgłowia. Maria obejmuje ciało Chrystusa, owinięte w całun i przytula się do jego policzka. Nad nimi stoi zapewne św. Jan, zaś po jego bokach aniołowie trzymają w rękach kadzielnice, krzyż i wiaderko z kropidłem. Przed sarkofagiem przyklękają szydzący żydzi, nieco zminiaturyzowani w stosunku do pozostałych uczestników Ztożenia do grobu. Również Fra Gulielmo na ambonie w kościele San Giovanni Fuorcivitas w Pistoi z 1270 r. umieścił dwóch aniołów w górnych rogach reliefu Złożenia do grobu, $z$ których jeden okadza ciało Jezusa ${ }^{23}$.

W Ochtinej przed sarkofagiem klęczy kobieta i wyciaga rękę, jakby chciała ująć dłoń martwego Chrystusa. Motyw ten był już rozważany przez Karen Gould w miniaturze ukazującej Ztożenie do grobu w Godzinkach (New York, Metropolitan Museum of Art, The Coisters Inv. 54.1.2. fol. 82v) malowanych przez Jeana Pucella dla Jeanne d'Evreux, w czasie kiedy była królową Francji, a więc od poślubienia Karola IV w 1324 r. do jej śmierci w 1328 r. Przy malowaniu tej sceny artysta posłużył się włoskim wzorem, zapewne wziętym z Maestà Duccia, a dotyczącym: ułożenia ciała Jezusa w sarkofagu, Marii tulącej swój policzek do twarzy Chrystusa, św. Jana podtrzymującego glowę Chrystusa i Józefa z Arymatei stojącego u stóp leżącego w grobie Zbawiciela, oraz kobiety załamującej ręce nad głową. Jednak kobieta przyklękająca przed sarkofagiem i ujmująca rękę Chrystusa jest jakby wprost przeniesiona $\mathrm{z}$ płaskorzeźby Zaśnięcia Marii w tympanonie poludniowym katedry w Strasburgu. Za Pucellem ten motyw kobiety przed sarkofagiem, rozpoznawanej jako Maria Magdalena i przytykającej dłoń Chrystusa do swojej twarzy, powtórzył Jean Le Noir w scenie Złożenia do grobu w Godzinkach Jeanne de Navarre (Paryż, Bibl. Nat. MS nouv. acp. Lat. 3145, fol. 115) ${ }^{24}$. Motyw ten znany jest $z$ czternastowiecznych płaskorzeźb wykonanych $w$ alabastrze w Anglii. Tutaj Maria Magdalena, klęcząc, siedząc czy stojąc przed sarkofagiem, trzyma za rękę Chrystusa, trzyma naczynie z olejkiem, lub wlasnymi włosami ociera krew $\mathrm{z}$ rany boku. Wszystkie te elementy mają związek $\mathrm{z}$ misteriami średniowiecznymi, w których nawiązano do ewangelicznej sceny obmycia stóp Jezusa przez Marię Magdalenę ( $\mathrm{kk} 7,38 ; \mathrm{J} 12,3)^{25}$. Jakim sposobem ten motyw znalazł się w Ochtinej, nie wiadomo. W każdym razie znajduje się on także na tablicy namalowanej w latach 1296-1327 we Florencji prawdopodobnie przez Lippo Benivieni (Pistoia, Museo Civico) ${ }^{26}$. Także widoczny jest w kwaterze ukazującej Zlożenie do grobu w ołtarzu autorstwa Mistrza z San Martino alla Palma, z drugiej lub trzeciej ćwierci XIV w. Ołtarz pochodzi prawdopodobnie z klasztoru Klarysek

${ }^{22}$ G. S c h ill e r, op. cit., il. 575 .

${ }^{23} \mathrm{G}$. S c h ill e r, op. cit., s. 175 , il. 599.

${ }^{24}$ K. Gould, Jean Pucelle and Northen Gothic Art: New Evidence from Strasbourg Cathedral, „Art Bulletin” 74, 1992, nr I, s. 52-53, 57-60, il. 9-13.

${ }^{25}$ W. L. H ild bu r g h, F. S. A., English Alabaster Carvings as Records of the Medieval Religious Drama, Archeologia or Miscellaneous Tracts relating to Antiquity, published by the Society of Antiquaries of London, 93 (second series, volume 43), Oxford--London 1949, 87-88, il. $19 \mathrm{~b}-\mathrm{d}$.

${ }^{26}$ M. G. R i c c i, Pistoia. Nuova guida città, Pistoia 2000, il. na s. 36. 
we Florencji, Monticelli lub Montedomini. ${ }^{27}$ Jednakże w tym przedstawieniu nie ma kobiety unoszącej ręce lub załamującj je nad głową. Kobieta klęczy przed sarkofagiem ze składanym w nim ciałem Jezusa także w kwaterze tryptyku Alegretto Nuziego, z lat 1369-1373 (w kolekcji prywatnej). W dziele dostrzeżono wpływ malarstwa florenckiego, nade wszystko Bernardo Daddiego ${ }^{28}$.

W Sliačach mężczyzna w nimbie trzyma w ręce naczynie, zapewne służące do namaszczenia ciała Jezusa. Według Ewangelii Janowej (J 19, 39) był to Nikodem, który przyniósł około stu funtów mieszaniny mirry i aloesu. Józef z Arymatei i Nikodem namaścili ciało Jezusa. Karta z rysunkami Zdjęcia z krzyża, Złożenia do grobu i scen związanych ze zmartwychwstaniem Chrystusa, datowana na około 1150 r. (Verdun, Bibl. Mun. 95, fol. 57 r.), zawiera opis każdej ze scen. Powyżej Zdjęcia z krzyża jest napisane: Nec deus est, nec homo, presens quem cernis imago/ Sed deus est et homo, presens quem signat imago. W scenie Zlozenia do grobu kobieta w nimbie trzyma zamknięte pokrywą naczynie, zaś jeden $\mathrm{z}$ dwóch mężczyzn trzyma naczynie otwarte i ma wyciagniętą prawą rękę w stronę złożnego $\mathrm{w}$ grobie Jezusa. Drugi z nich ujmuje Chrystusowe nogi ${ }^{29}$. Namaszczenie ciała następuje w scenach: na kapitelu kolumny zachodniej fasady katedry w Chartres (1150-1155), na relikwiarzu Panny Marii w Achen (lata 1220-1238), w miniaturze Psałterza Ingeburgi (około 1210 r.), w scenie na ołtarzu Godzinek kanonicznych z katedry w Lubece (pierwsza ćwierć XV w.), a także na ołtarzu Tomasza Becketa Mistrza Francke, w Hamburgu, z początku 1424 r. i w predelli Jeana Mirailleta w Nicei, $z$ pierwszej połowy XV w. ${ }^{30}$ Piętnastowieczne przedstawienia są pierwowzorem dla malowidła w Sliačach. Od śtrony głowy i nóg Chrystusa usytuowane są postacie, które pełnią funkcję w namaszczeniu Chrystusa.

W Starým Plzencu sceny Optakiwania i Zlożenia do grobu następują po sobie i są ukazane oddzielnie. Są świadectwem rozdzielności tych scen i w Optakiwaniu, a nie w Zlożeniu do grobu jak w innych powyższych scenach Maria lub jedna $z$ kobiet ma uniesione do góry ręce na znak lamentacji. Wydaje się, że głowę Chrystusa podpiera Maria Magdalena, a nogi podtrzymuje św. Jan. Obie postacie mają nimb wokół głowy, podobnie jak Maria siedzaca pośrodku, unosząca ręce nad ciałem złożonym na jej kolanach. W genezie przedstawien Piety średniowiecznej jest to rodzaj Piety, podobnej do późniejszego schematu z 1390 r. w kwaterze poliptyku w kościele Wniebowzięcia NMP w Toruniu, gdzie po bokach Marii trzymającej martwe ciało Jezusa na kolanach klęczą Symeon Starzec $i$ św. Jan Ewangelista ${ }^{31}$. Jednakże w naszym przypadku nie ma nawiązania do dzieciństwa Chrystusa, tylko wyrażenie lamentu Marii po zdjęciu z krzyża jej Syna.

${ }^{27}$ M. Boskovits, Frïhe italienische Malerei. Gemäldegalerie Berlin, Katalog der Gemälde, Berlin 1988, s. 128-131, il. 190.

${ }^{28}$ G. F r e u l e r, Katalog, [w:] , Kïnder der wunderbaren Dinge”. Frühe italienische Malerei aus Sammlungen in der Schweiz und in Liechtenstein, Lugano-Castagnola 1991, kat. 72, s. 194-196, il.na s. 195.

${ }^{29}$ J. F. H a m bu r g e r, A Liber Precum in Sélestat and the Development of the Illustrated Prayer Book in Germany, „Art Bulletin” 73 nr 2, s. 228, il. 27.

${ }^{30}$ G. S c hille r, dz. cyt., s. 171-173, il. 579, 587-591.

${ }^{31}$ L. K a 1 in ow k i, Geneza Piety średniowiecznej, Prace Komisji Historii Sztuki, X, 1952, s. 232, il. 27; T. D o b r z e n i c k i, Malarstwo tablicowe, katalog zbiorów, Warszawa 1972, s. 100-] 17, il. 33F4. 
W powyższych przedstawieniach $w$ geście uniesionych rąk jest wyrażone albo Oplakiwanie, albo uczucia związane ze Zlożeniem do grobu, gdzie do tego wyobrażenia przeniesiono między innymi gest uniesienia rąk ze sceny Optakiwania. Głównym źródłem obrazowania w powyższych dziełach zdaje się być sztuka wloska, obecna w przedstawieniach Europy Zachodniej. Podłożem dla niej są rozwiązania ikonograficzne w sztuce bizantyńskiej.

\section{Provenance of Some Iconographic Patterns of Christ's Passion in Medieval Wall Painting in Slovakia and the Czech Republic Summary}

In the depictions presented in the article the gesture of raised hands expresses either Mourning or the feelings connected with Entombing, whose image is supplemented by the gesture of raised hands from the scene of Mourning, among others. The main source of illustration in these works seems to be Italian art, present in Western European painting. Its basis are iconographic solutions of the Byzantine art. 
1. Opłakiwanie, Starý Plzenec.
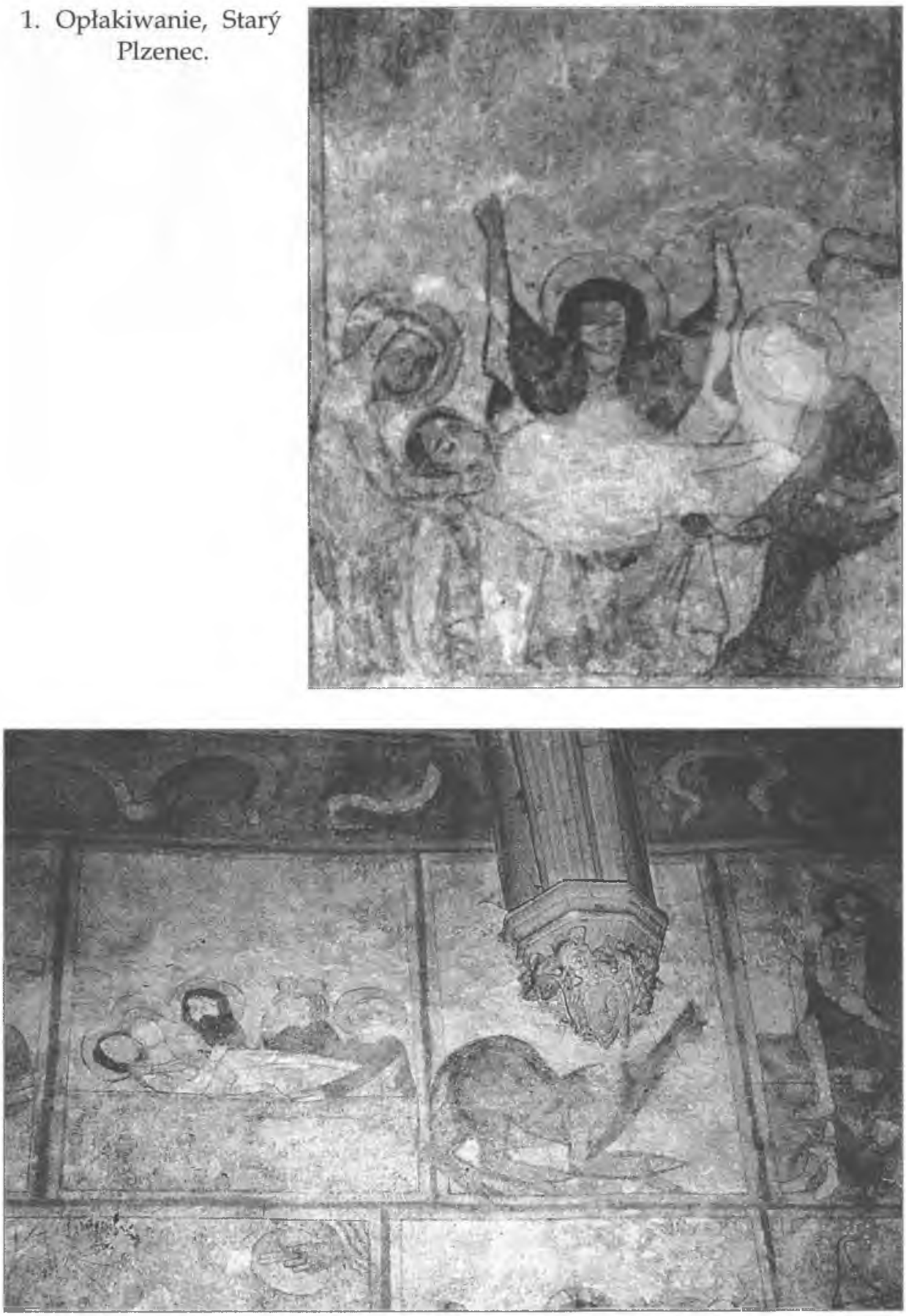

2. Złożenie do grobu, Starý Plzenec. 


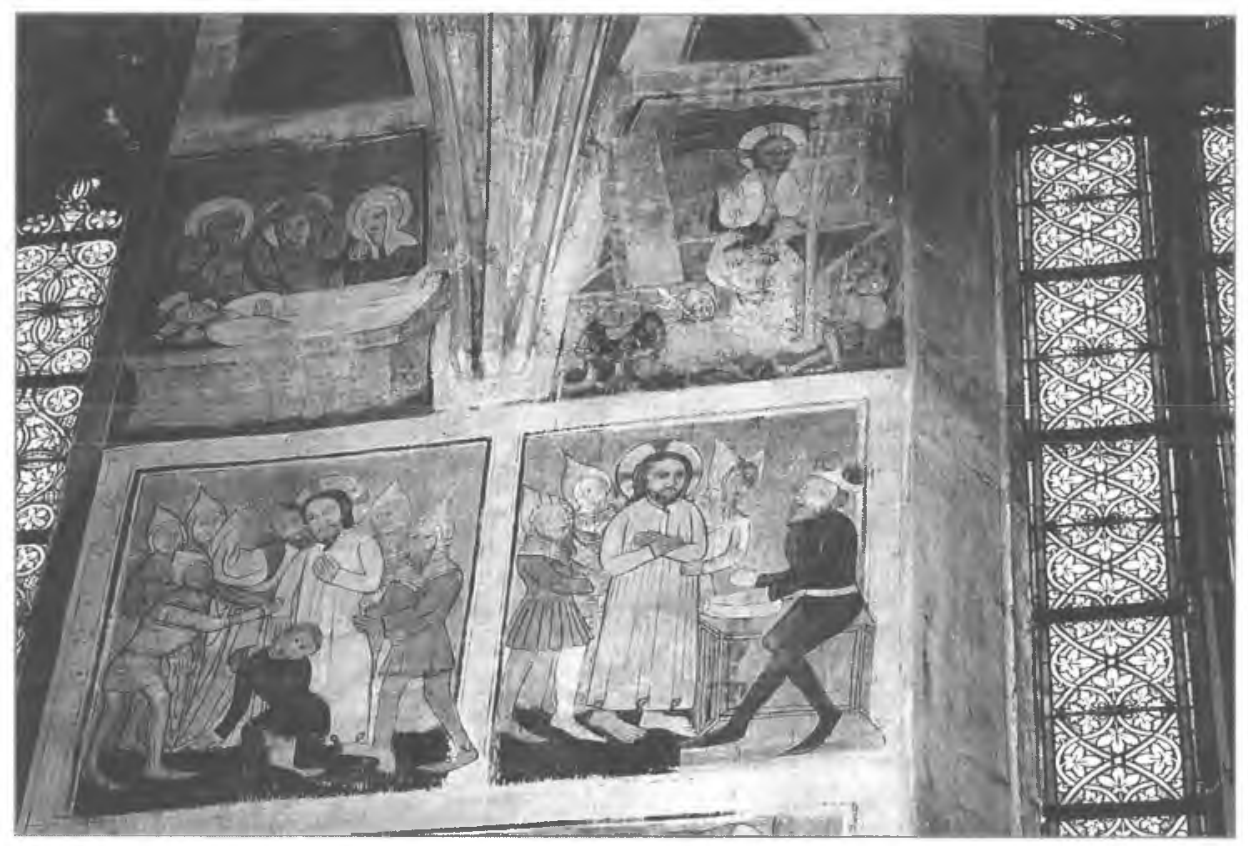

3. Złożenie do grobu, Slavětin.

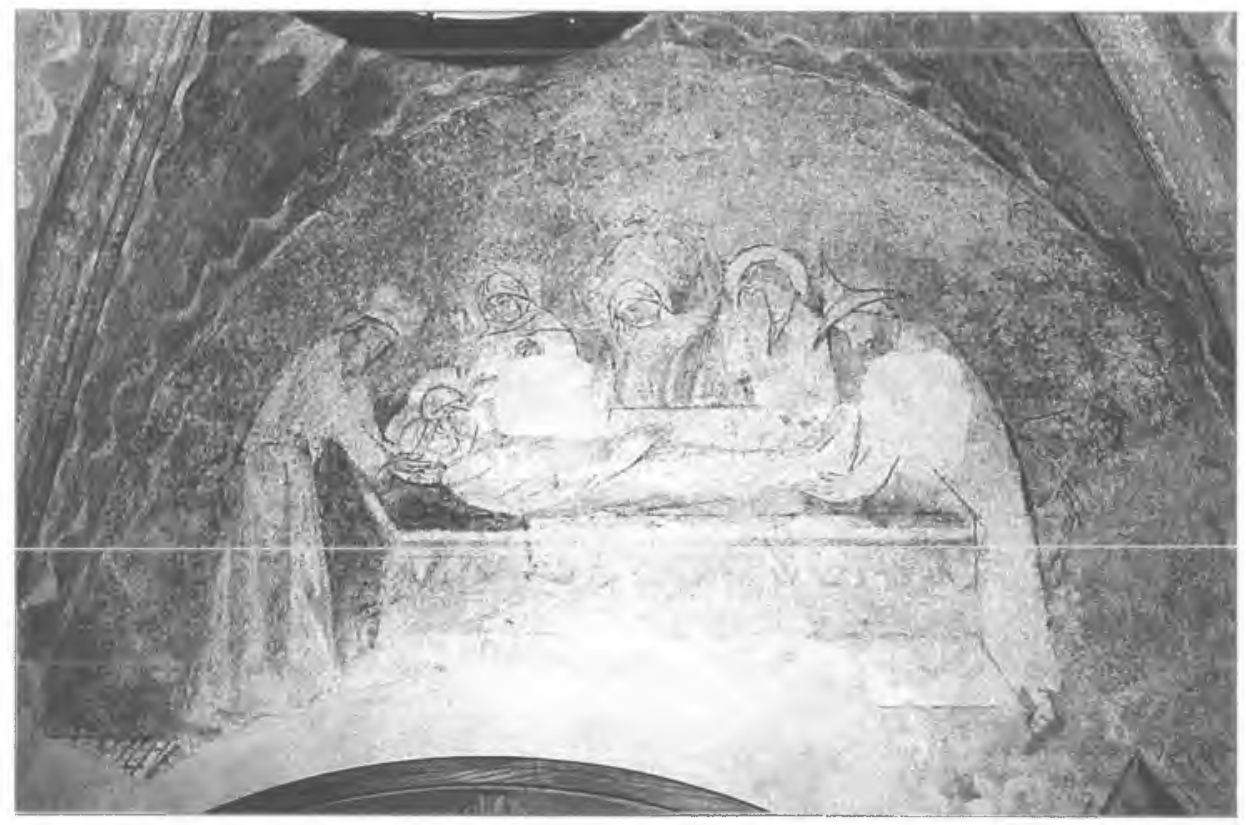

4. Złożenie do grobu, Zablati. 


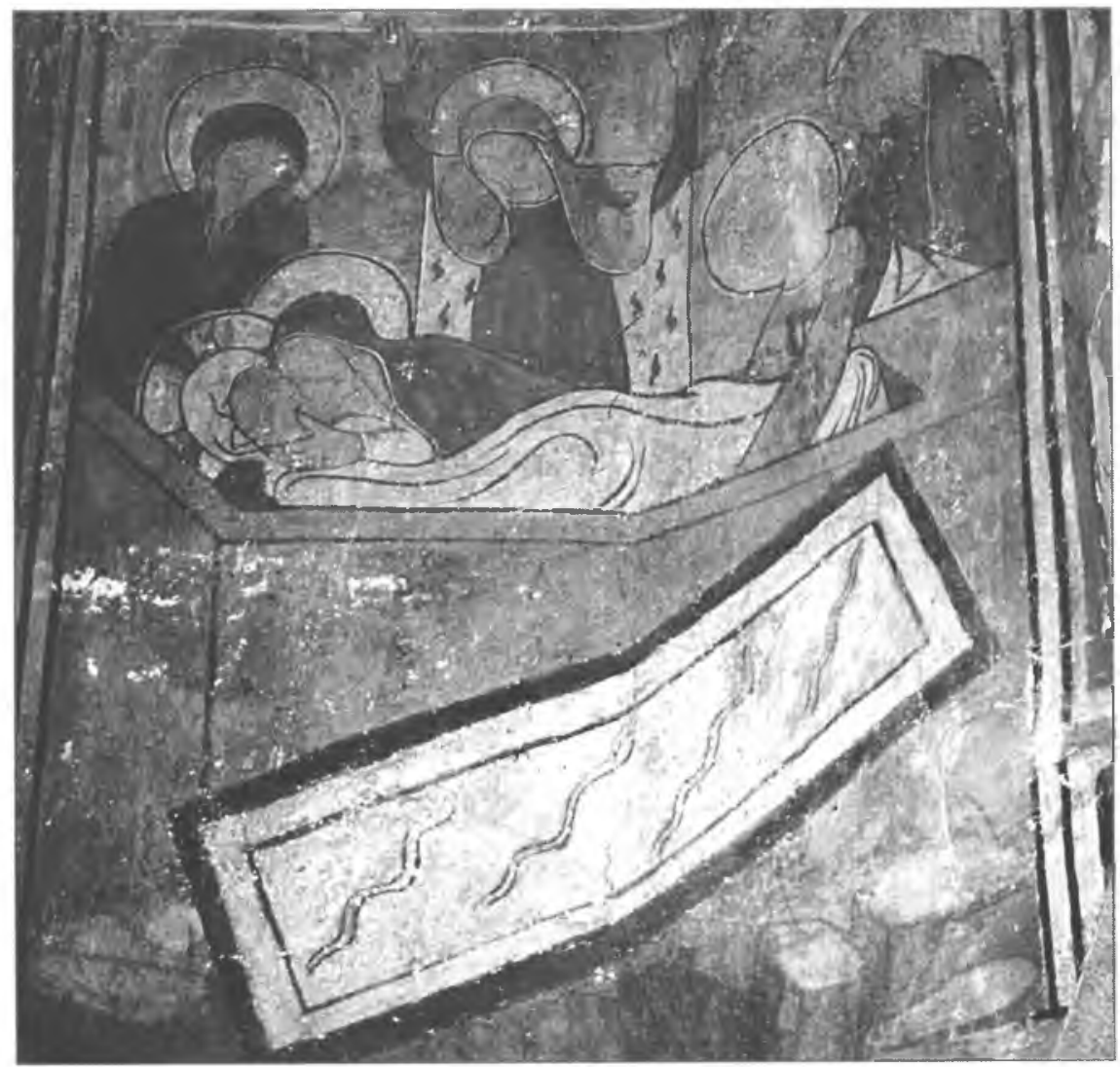

5. Złożenie do grobu, Podolinec. 


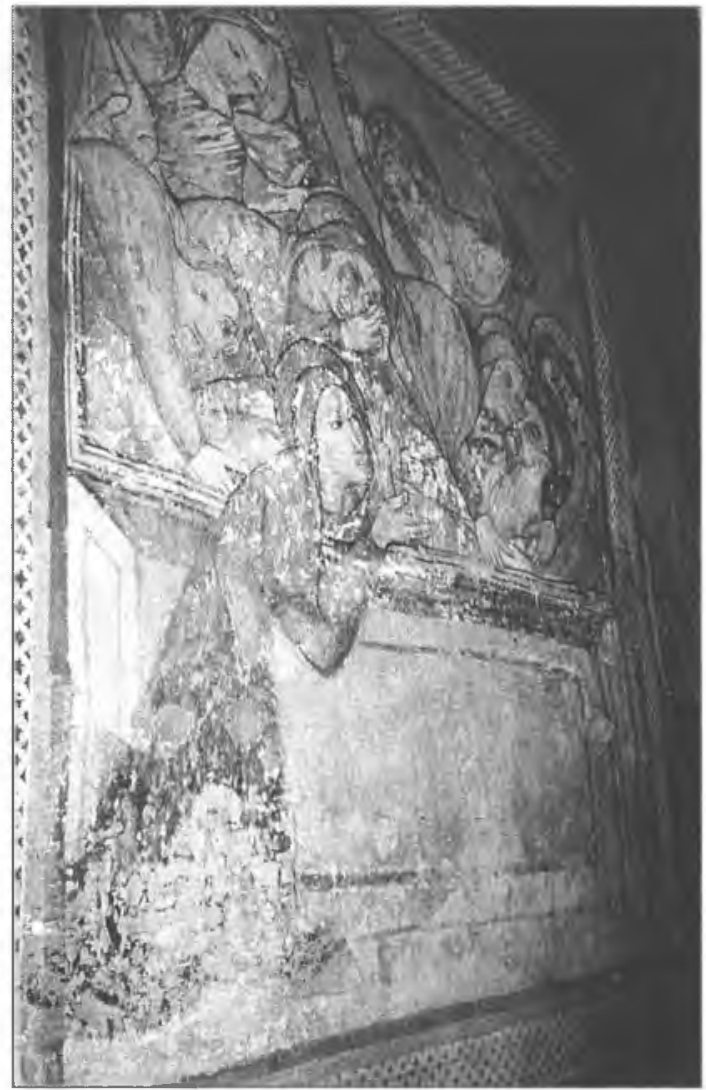

6. Złożenie do grobu, Ochtina. 

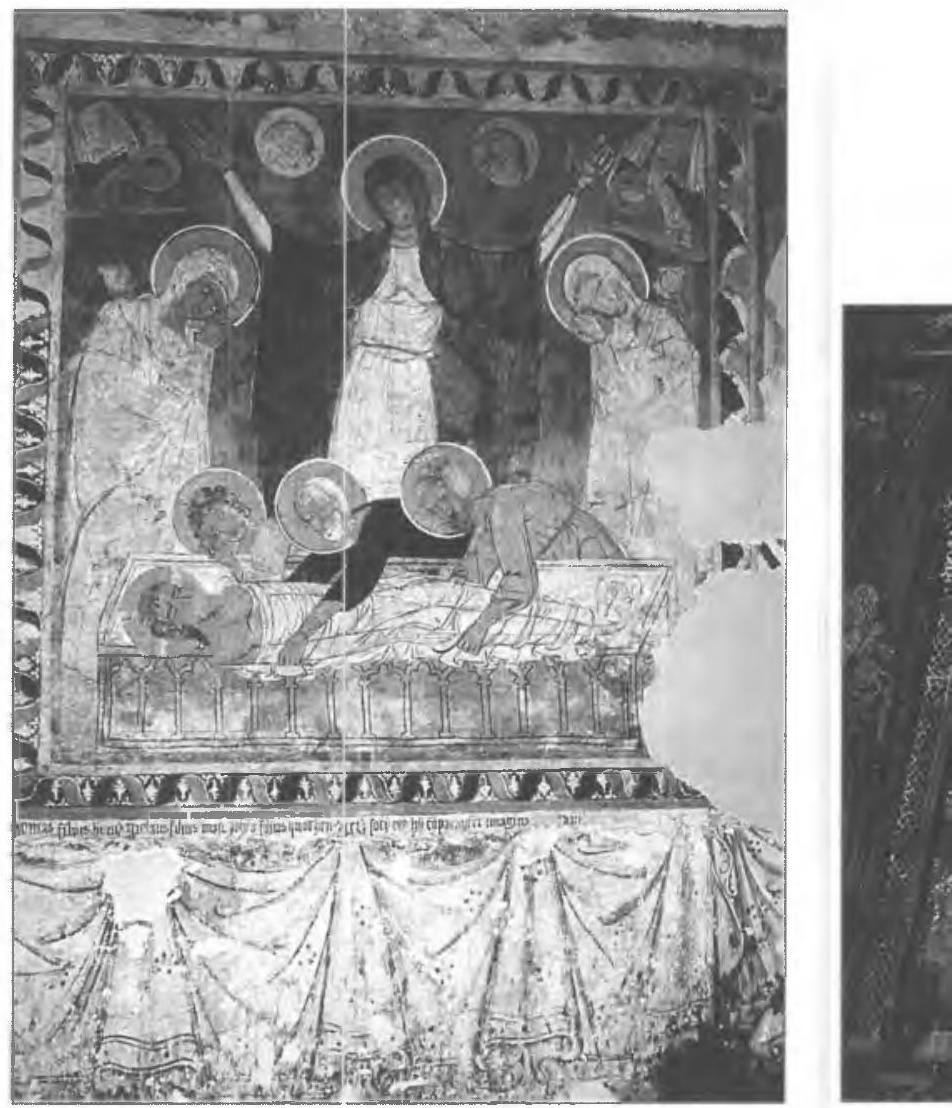

\section{Złożenie do grobu, Zolna.}




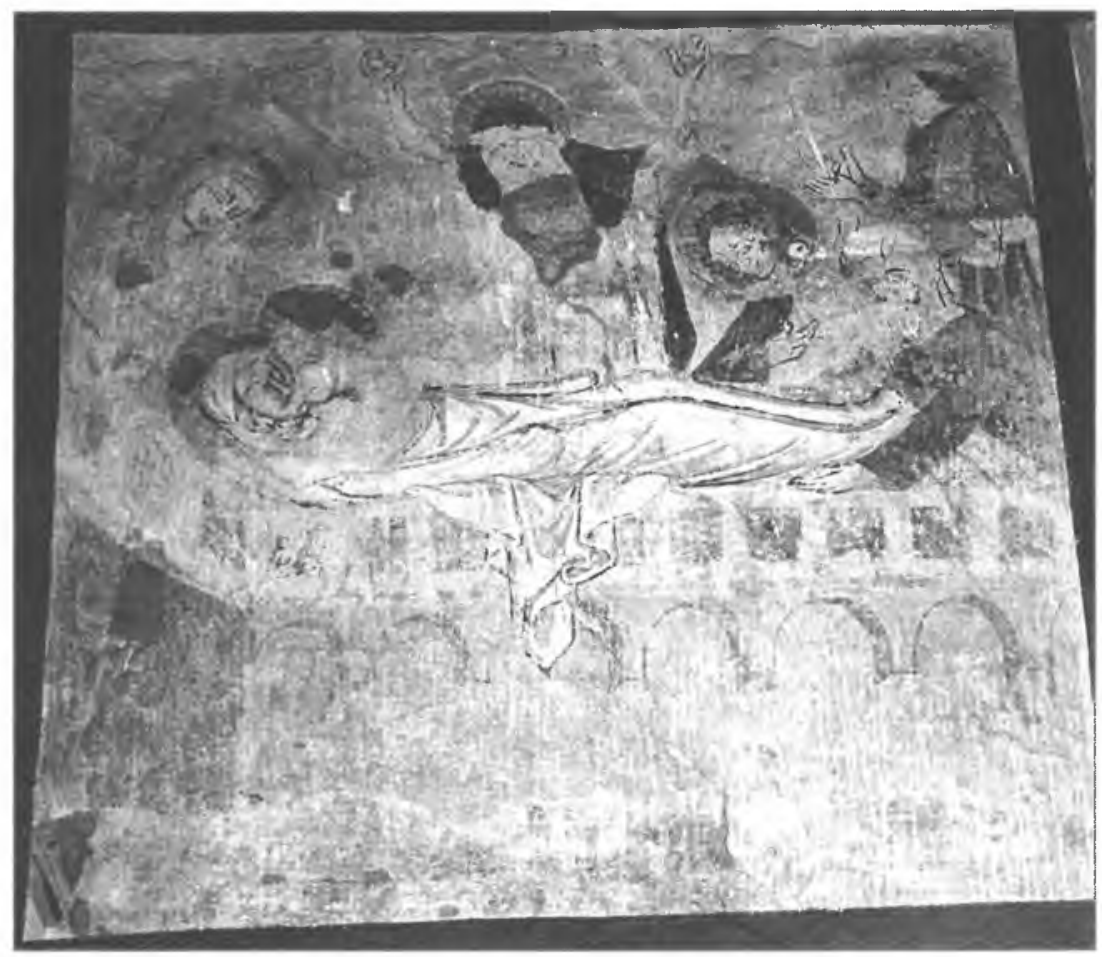

9. Złożenie do grobu, Švábovce.

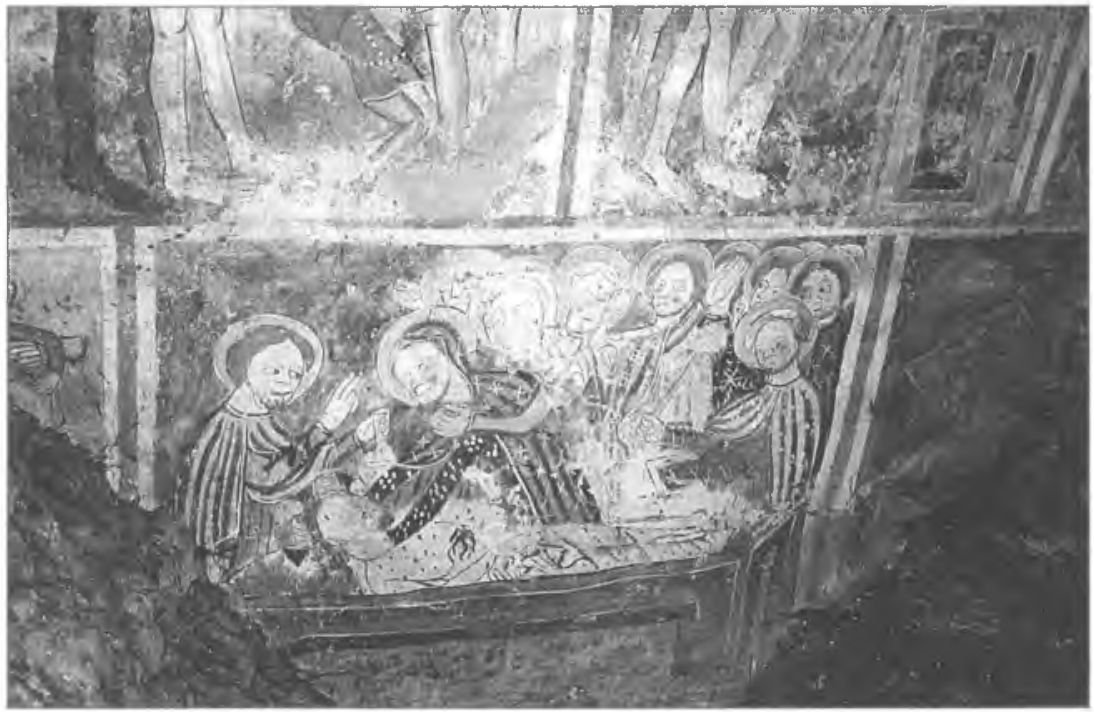

10. Złożenie do grobu, Sliače. 